University of Nebraska - Lincoln

DigitalCommons@University of Nebraska - Lincoln

2020

\title{
Camera Traps Detect Prey of Northern Carnivores
}

David A. Keiter

University of Nebraska-Lincoln, david.keiter@gmail.com

Brent R. Patterson

Ontario Ministry of Natural Resources and Forestry

Carol Dersch

Lake Superior Provincial Park

Bob Elliott

Lake Superior Provincial Park

Arthur R. Rodgers

OMNRF, Centre for Northern Forest Ecosystem Research

See next page for additional authors

Follow this and additional works at: https://digitalcommons.unl.edu/natrespapers

Part of the Natural Resources and Conservation Commons, Natural Resources Management and Policy Commons, and the Other Environmental Sciences Commons

Keiter, David A.; Patterson, Brent R.; Dersch, Carol; Elliott, Bob; Rodgers, Arthur R.; and Benson, John F., "Camera Traps Detect Prey of Northern Carnivores" (2020). Papers in Natural Resources. 1366.

https://digitalcommons.unl.edu/natrespapers/1366

This Article is brought to you for free and open access by the Natural Resources, School of at DigitalCommons@University of Nebraska - Lincoln. It has been accepted for inclusion in Papers in Natural Resources by an authorized administrator of DigitalCommons@University of Nebraska - Lincoln. 


\section{Authors}

David A. Keiter, Brent R. Patterson, Carol Dersch, Bob Elliott, Arthur R. Rodgers, and John F. Benson 


\title{
Notes of the Northeastern Naturalist, Issue 27/2, 2020
}

\section{Camera Traps Detect Prey of Northern Carnivores}

David A. Keiter ${ }^{1, *}$, Brent R. Patterson ${ }^{2}$, Carol Dersch ${ }^{3}$, Bob Elliott ${ }^{3}$, Arthur R. Rodgers ${ }^{4}$, and John F. Benson ${ }^{1}$

\begin{abstract}
Use of camera traps for non-invasive data collection is increasingly common in wildlife studies. This technique presents a valuable, but generally unexploited, opportunity to learn about carnivore diet through direct observations of predators with prey. To highlight this potential, we present a collection of photographic observations from Michipicoten Island, ON, Canada, that improve our knowledge of the diets of northern carnivores. These include the first documentation of Vulpes vulpes (Red Fox) consumption of a Colaptes auratus (Northern Flicker) and the first photographic evidence of wintertime consumption of a Lithobates sp. (frog) by a Mustela erminea (Short-tailed Weasel). We discuss the implications of these observations and the use of camera traps to gather data on carnivore diets, including caveats to this technique.
\end{abstract}

Camera traps are often used to monitor wildlife populations, assess the influence of perturbations on wildlife, and evaluate interactions among species within a community (reviewed in O'Connell et al. 2011). Furthermore, camera traps are increasingly employed for large-scale regional and even global research projects due to their non-invasive nature and relative cost-effectiveness (e.g., Ahumada et al. 2011). One opportunity that has been relatively neglected is the ability to study the diet of predators with photographs of predation events or of predators with the carcasses of prey (but see Windell et al. 2019). For example, a recent study employing camera traps was the first to document predation of a Cervus nippon Temminck (Sika Deer) by an Aquila chrysaetos L. (Golden Eagle) in eastern Russia (Kerley and Slaght 2013). To further highlight the value of camera traps for determination of novel or cryptic components of predator diets, we present a collection of photographic observations from Michipicoten Island, ON, Canada, that improve our knowledge of prey consumption by 2 common northern carnivores. Among these observations is, to our knowledge, the first documentation of consumption of a Colaptes auratus L. (Northern Flicker) by a Vulpes vulpes L. (Red Fox) and the first photographic evidence of wintertime consumption of a Lithobates sp. (frog) by a Mustela erminea L. (Short-tailed Weasel).

Michipicoten Island $\left(184 \mathrm{~km}^{2}\right)$ is located in northeastern Lake Superior $\sim 16 \mathrm{~km}$ from mainland Ontario. At the time of the study, Michipicoten Island was primarily an Ontario Provincial Park, although it contained a handful of private and federal government properties (Ontario Parks 2004). Michipicoten Island was $~ 87 \%$ forested, mostly by deciduous tree species (e.g., Acer saccharum Marsh [Sugar Maple], Betula papyrifera Marshall [Paper Birch], and Betula alleghaniensis Britton [Yellow Birch]; Ontario Parks 2004). Mammalian carnivore species that have been documented on Michipicoten Island in recent years are Canis lupus L. (Gray Wolf), Red Fox, and Short-tailed Weasel (Ontario Ministry of Natural Resources and Forestry, Wildlife Research and Monitoring Section, Peterborough, ON, Canada, unpubl. data). Other mammals present include Castor canadensis Kuhl (American

\footnotetext{
${ }^{1}$ University of Nebraska-Lincoln, School of Natural Resources, Hardin Hall, 3310 Holdrege Street, Lincoln, NE 68583-0995. ${ }^{2}$ Ontario Ministry of Natural Resources and Forestry [OMNRF], Wildlife Research and Monitoring Section, 2140 East Bank Drive, Peterborough, ON K9J 7B8, Canada. ${ }^{3}$ OMNRF, Ontario Parks, Lake Superior Provincial Park, PO Box 267, Park Floor 1, Wawa, ON P0S 1K0, Canada. ${ }^{4}$ OMNRF, Centre for Northern Forest Ecosystem Research, 103-421 James Street South, Thunder Bay, ON P7E 2V6, Canada. *Corresponding author - david.keiter@gmail.com.
}

Manuscript Editor: Joshua Ness 
D.A. Keiter, B.R. Patterson, C. Dersch, B. Elliott, A.R. Rodgers, and J.F. Benson

Beaver), Lepus americanus Erxleben (Snowshoe Hare), Ondatra zibethicus L. (Muskrat), and Tamiasciurus hudsonicus Erxleben (Red Squirrel). Rangifer tarandus caribou Gmelin (Boreal Woodland Caribou) were also present on Michipicoten Island until spring 2018, when the population appears to have been extirpated. Michipicoten Island also provides habitat for a number of bird and herpetofauna species.

In late summer and fall 2014, we placed motion-activated camera traps (Reconyx HC600 HyperFire; Reconyx Inc., Holmen, WI) at 6 locations around the periphery of Michipicoten Island as part of a monitoring campaign for Boreal Woodland Caribou. We deployed cameras on trees 1.5-2 $\mathrm{m}$ above the ground along trails and programmed them to take 5 pictures in quick succession when triggered, with no delay between triggering events. These cameras operated continuously since their deployment. In summer 2018, we deployed an additional 30 cameras (Reconyx HC600 HyperFire and Reconyx UltraFire XR6; Reconyx Inc., Holmen, WI, USA) along trails on Michipicoten Island. We initially baited these camera traps with a predator attractant (fatty acid tablet; US Department of Agriculture, Pocatello Supply Depot, Pocatello, ID) placed 2-3 m from the camera on the ground. We recovered these 30 cameras in spring of 2019 and recorded all observations of wildlife species from these and the previously deployed cameras. All research was conducted with permission from and in cooperation with Ontario Parks.

During our study, we recorded 9 distinct observations of northern mammalian carnivores with prey carcasses (Table 1). We cannot definitively rule out that prey items were scavenged rather than killed by the predators, but all prey carcasses appeared relatively intact and were not obviously degraded. We identified prey items by morphological characteristics. We observed Red Foxes carrying Snowshoe Hare carcasses 5 times and a Short-tailed Weasel carrying a small mammal (order: Rodentia) carcass once. These observations are unsurprising as these are common prey species for these predators throughout their range (e.g., Edwards and Forbes 2003, Sievert and Keith 1985). We also observed a Red Fox with the carcass of an Anatidae (duck) in early March 2017. Adult ducks are relatively common in Red Fox diets, although most previous predation has been documented in summer, rather than winter. Two further observations of predators with prey were particularly notable.

First, in August 2018, we captured a photograph of a Red Fox simultaneously carrying the carcasses of a Northern Flicker and a Red Squirrel (Fig. 1A). Birds often make up a relatively small proportion of Red Fox diets (reviewed in Díaz-Ruiz et al. 2013, Soe et al. 2017) and have generally not been identified to species. Past studies of Red Fox diet have

Table 1. Camera trap observations of predators with prey carcasses, Michipicoten Island, Ontario 2014-2019.

\begin{tabular}{lclll} 
Camera ID & Date & Time & Predator & Prey item(s) \\
\hline EE & $2017-03-08$ & $00: 14$ & Vulpes vulpes & Family Anatidae \\
EE & $2017-03-22$ & $18: 09$ & Vulpes vulpes & Lepus americanus \\
Cam09 & $2018-11-24$ & $07: 54$ & Mustela erminea & Lithobates spp. \\
Cam13 & $2018-08-27$ & $21: 58$ & Vulpes vulpes & Lepus americanus \\
Cam13 & $2018-08-29$ & $19: 10$ & Vulpes vulpes & Colaptes auratus and \\
& & & & Tamiasciurus hudsonicus \\
Cam13 & $2018-09-09$ & $21: 39$ & Vulpes vulpes & Lepus americanus \\
Cam13 & $2018-09-12$ & $19: 51$ & Vulpes vulpes & Lepus americanus \\
Cam14 & $2018-08-15$ & $20: 47$ & Vulpes vulpes & Lepus americanus \\
Cam23 & $2018-11-10$ & $06: 31$ & Mustela erminea & Order Rodentia \\
\hline
\end{tabular}


D.A. Keiter, B.R. Patterson, C. Dersch, B. Elliott, A.R. Rodgers, and J.F. Benson

mostly reported consumption of Columba spp. (pigeons and doves), Anas spp. (dabbling ducks), and members of order Galliformes (quail, grouse, and pheasants) (e.g., Baker et al. 2006, Díaz-Ruiz et al. 2013, Sargeant et al. 1984). Previously reported predators of adult woodpeckers include raptors (e.g., Accipiter cooperii Bonaparte [Cooper's Hawk], Accipiter striatus Vieillot [Sharp-shinned Hawk]; Kilgo and Vukovich 2012) and other predators that can capture woodpeckers at their nest sites in tree cavities (e.g. snakes, members of the family Mustelidae [weasels], Procyon lotor L. [Northern Raccoon], Ursus americanus Pallas [Black Bear], and members of family Sciuridae [squirrels]; Elchuk and Wiebe 2002, Kilgo and Vukovich 2012, Packlík et al. 2009). To date, predation of woodpeckers on the ground has rarely been observed, although recent evidence suggests that the invasive Neovison vison Schreber (American Mink) may capture Campephilus magellanicus King (Magellanic Woodpeckers) during terrestrial foraging (Jiménez et al. 2014). Unlike all other North American woodpeckers, which forage for insect larvae in trees, Northern Flickers almost exclusively exhibit terrestrial foraging during the summer (Elchuk and Wiebe 2002). As such, among woodpeckers, Northern Flickers may be particularly vulnerable to predation by terrestrial carnivores, including Red Foxes.

Second, in November 2018, we photographed a Short-tailed Weasel with the carcass of either a Lithobates catesbeianus Shaw (American Bullfrog) or Lithobates clamitans Latreille (Green Frog), both of which are present on Michipicoten Island (Fig. 1B). While the diet of Short-tailed Weasels is generally dominated by lagomorphs, rodents, and small birds (e.g., Edwards and Forbes 2003, McDonald et al. 2000), winter consumption of amphibians has been documented previously (e.g., Sidorovich and Pikulik 1997). However, at the time of this photograph, there was snow on the ground and temperatures in the area had been below freezing for at least 2 weeks. This photograph and previous records of winter amphibian consumption by Short-tailed Weasels suggest 3 possibilities. First, small mustelids including Short-tailed Weasels sometimes cache food for later consumption (King and Powell 2007). It is possible that we observed a Short-tailed Weasel with the carcass of an amphibian that it had killed and cached prior to the beginning of amphibian hibernation. However, this explanation also implies that prey consumption, at least in this

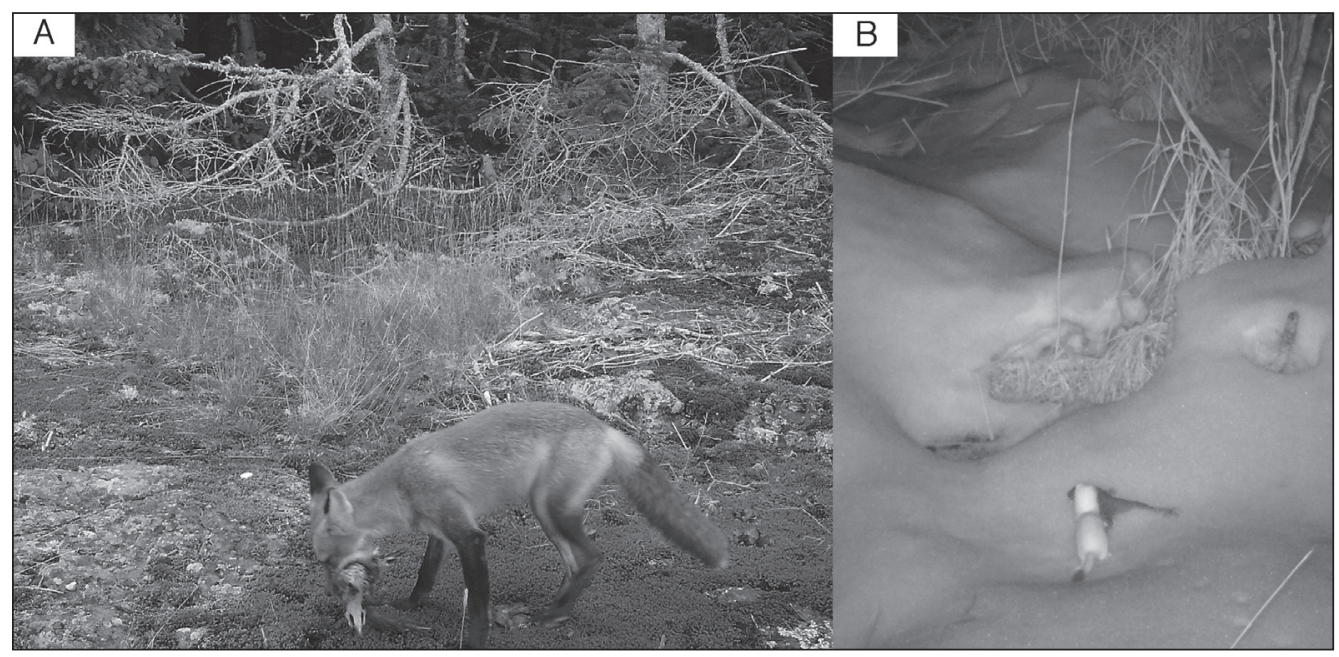

Figure 1. Camera trap photographs of (A) a Vulpes vulpes (Red Fox) simultaneously carrying Colaptes auratus (Northern Flicker) and Tamiasciurus hudsonicus (Red Squirrel) carcasses, and (B) wintertime consumption of a Lithobates (frog) by a Mustela erminea (Short-tailed Weasel), on Michipicoten Island, ON, 2018. 
D.A. Keiter, B.R. Patterson, C. Dersch, B. Elliott, A.R. Rodgers, and J.F. Benson

case, did not take place at the cache location, which would be somewhat surprising, as weasels are suggested to use cache sites to reduce the necessity of hunting and exposure to energetically demanding conditions (King and Powell 2007). Second, many amphibians use small mammal burrows facultatively to escape thermal stress (Lannoo 2005). The weasel may have encountered the frog while searching small mammal burrows for other prey. Finally, it is possible that the weasel excavated a hibernating frog from its burrow within the soil substrate. While this behavior has not been established for Shorttailed Weasels, it has been documented in related Mustela putorius L. (European Polecat; Jedrzejewska and Jedrzejewska 1998), which more commonly feed on amphibians in winter. Further research could help clarify the behavioral strategies associated with winter consumption of amphibians by Short-tailed Weasels.

With widespread use of camera traps to monitor wildlife populations and conduct research, we believe that there will be increased opportunity to identify novel or cryptic components of carnivore diets and sources of mortality for prey, as in this study. For example, camera trapping by Brzeziński et al. (2014) recently documented predation of Red Fox cubs by a Martes martes L. (European Pine Marten), a reversal of commonly observed intraguild predation of Pine Martens by Red Foxes. While observations of this type may currently be relatively infrequent, they can offer important insight into interactions between wildlife species, albeit with some important caveats.

Similar to other methods of assessing predator diet, a number of limitations likely exist regarding the use of camera traps to identify prey consumed by predators. First, predator behavior and ecology will likely bias the timing and frequency of these observations. For example, carnivores that exhibit high levels of parental care may be observed with prey items more frequently during offspring-rearing as a result of food-provisioning behavior (Malcolm 1985). This may explain why a number of our observations of Red Foxes with prey occurred in the late summer and early fall. Similarly, placement of camera traps could influence the probability of detecting prey consumption by carnivores, as cameras closer to den sites might be more likely to detect predators returning with prey. Predator and prey size may also influence which species are observed carrying prey (Windell et al. 2019). Finally, certain predators may exhibit immediate consumption of prey, while others cache food (e.g., mustelids; King and Powell 2007) and thus may have increased likelihood of being photographed with a prey carcass.

Despite these caveats, camera traps offer a means to determine novel relationships between predators and prey by improving our ability to determine specific dietary components for carnivores and infer possible foraging behaviors, as this note demonstrates. Due to the relative infrequency of these observations and the potential biases noted above, we do not believe that camera traps alone will allow for accurate assessment of predator diets. However, beyond simply documenting consumption of novel prey, these observations may prove useful in guiding sampling for other diet-estimation techniques. For example, camera-trap observations could allow researchers to conduct targeted collection of prey samples for use in stable isotope analysis. In addition, with the recent creation of databases that compile camera-trap photos from a wide variety of locations and studies (e.g., eMammal; McShea et al. 2016), observations of this nature could be combined across broader spatial and temporal extents in the future to provide greater understanding of the relationships between predator and prey species.

Acknowledgments. We would like to thank all Ontario Ministry of Natural Resources and Forestry (OMNRF) and Ontario Parks personnel and volunteers who helped conduct the fieldwork for this project, particularly A. Preston. Funding for this research was provided by the Wildlife Research and 
D.A. Keiter, B.R. Patterson, C. Dersch, B. Elliott, A.R. Rodgers, and J.F. Benson

Monitoring Section of the OMNRF, the OMNRF Species at Risk Research Fund for Ontario, and the School of Natural Resources at the University of Nebraska-Lincoln.

\section{Literature Cited}

Ahumada, J.A., C.E.F. Silva, K. Gajapersad, C. Hallam, J. Hurtado, E. Martin, A. McWilliam, B. Mugerwa, T. O’Brien, F. Rovero, D. Shiel, W.R. Spironello, N. Winarni, and S.J. Andelman. 2011. Community structure and diversity of tropical forest mammals: Data from a global camera trap network. Philosophical Transactions of the Royal Society B: Biological Sciences 366:2703-2711.

Baker, P., M. Furlong, S. Southern, and S. Harris. 2006. The potential impact of Red Fox, Vulpes vulpes, predation in agricultural landscapes in lowland Britain. Wildlife Biology 12:39-50.

Brzeziński, M., Ł. Rodak, and A. Zalewski. 2014. "Reversed" intraguild predation: Red Fox cubs killed by Pine Marten. Acta Theriologica 59:473-477.

Díaz-Ruiz, F., M. Delibes-Mateso, J.L. García-Moreno, M. López-Martín, C. Ferreira, and P. Ferreras. 2013. Biogeographical patterns in the diet of an opportunistic predator: The Red Fox, Vulpes vulpes, in the Iberian Peninsula. Mammal Review 43:59-70.

Edwards, M.A., and G.J. Forbes. 2003. Food habits of Ermine, Mustela erminea, in a forested landscape. Canadian Field Naturalist 117:245-248.

Elchuk, C.L., and K.L. Wiebe. 2002. Food and predation risk as factors related to foraging locations of Northern Flickers. Wilson Journal of Ornithology 114:349-358.

Jędrzejewska, B. and W. Jędrzejewski. 1998. Predation in Vertebrate Communities: The Białowieża Primeval Forest as a Case Study. Springer Verlag, Berlin, Germany. 450 pp.

Jiménez, J.E., R.D. Crego, G.E. Soto, I. Román, R. Rozzi, and P.M. Vergara. 2014. Potential impact of the alien American Mink (Neovison vison) on Magellanic Woodpeckers (Campephilus magellanicus) in Navarino Island, Southern Chile. Biological Invasions 16:961-966.

Kerley, L.L., and J.C. Slaght. 2013. First documented predation of a Sika Deer (Cervus nippon) by Golden Eagle (Aquila chrysaetos) in Russian far east. Journal of Raptor Research 47:328-331.

Kilgo, J.C., and M. Vukovich. 2012. Factors affecting breeding season survival of Red-headed Woodpeckers in South Carolina. Journal of Wildlife Management 76:328-335.

King, C.M., and R.A. Powell. 2007. The Natural History of Weasels and Stoats: Ecology, Behavior, and Management. Oxford University Press, Oxford, UK. 446 pp.

Lannoo, M.J. 2005. Amphibian Declines: The Conservation Status of United States Species. University of California Press, Berkeley, CA. 1115 pp.

Malcolm, J.R. 1985. Paternal care in canids. American Zoologist 25:853-856.

McDonald, R.A., C. Webbon, and S. Harris. 2000. The diet of Stoats (Mustela erminea) and Weasels (Mustela nivalis) in Great Britain. Journal of Zoology 252:363-371.

McShea, W.J., T. Forrester, R. Costello, Z. He, and R. Kays. 2016. Volunteer run cameras as distributed sensors for macrosystem mammal research. Landscape Ecology 31:55-66.

Meek, P.D., and J. Wishart. 2017. Camera trap evidence of Red Fox (Vulpes vulpes) predation attempts on adult macropods. Pacific Conservation Biology 23:302-305.

O'Connell, A.F., J.D. Nichols, and K.U. Karanth. 2011. Camera Traps in Animal Ecology: Methods and Analyses. Springer, New York, NY. 279 pp.

Ontario Parks. 2004. Michipicoten Post and Michipicoten Island: Background information. Queens Printer of Ontario, Ottawa, ON, Canada.

Paclík, M., J. Misík, and K. Weidinger. 2009. Nest predation and nest defence in European and North American woodpeckers: A review. Annales Zoologici Fennici 46:361-379

Sargeant, A.B., S.H. Allen, and R.T. Eberhardt. 1984. Red Fox predation on breeding ducks in midcontinent North America. Wildlife Monographs 89:3-41.

Sidorovich, V.E., and M.M. Pikulik. 1997. Toads, Bufo spp., in the diets of mustelid predators in Belarus. Acta Theriologica 42:105-108.

Sievert, P.R., and L.B. Keith. 1985. Survival of Snowshoe Hares at a geographic range boundary. Journal of Wildlife Management 49:854-866. 
D.A. Keiter, B.R. Patterson, C. Dersch, B. Elliott, A.R. Rodgers, and J.F. Benson

Soe, E., J. Davison, K. Süld, H. Valdmann, L. Laurimaa, and U. Saarma. 2017. Europe-wide biogeographical patterns in the diet of an ecologically and epidemiologically important mesopredator, the Red Fox, Vulpes vulpes: A quantitative review. Mammal Review 47(3):198-211.

Windell, R.M., J.S. Lewis, A.R. Gramza, and K.R. Crooks. 2019. Carnivore carrying behavior as documented with wildlife camera traps. Western North American Naturalist 79(4):471-480. 